\title{
MYB/NFIB Fusion Protein
}

National Cancer Institute

\section{Source}

National Cancer Institute. MYB/NFIB Fusion Protein. NCI Thesaurus. Code C129773.

A fusion protein encoded by the MYB/NFIB fusion gene. This protein is comprised of most of transcriptional activator Myb protein fused to the amino acids comprising the extreme C-terminus of nuclear factor 1 B-type protein. 